\title{
Iron deficiency anemia (IDA) in preschool children of district Dir Lower Khyber Pakhtoonkhwa Pakistan
}

\author{
Atiq Ur Rahman ${ }^{1}$, Muhammad Zahid ${ }^{1 *}$ and Amjad Ali ${ }^{2}$ \\ 1. Department of Zoology, Islamia College Peshawar Khyber Pakhtoonkhwa-Pakistan \\ 2. Department of Statistics, Islamia College Peshawar Khyber Pakhtoonkhwa-Pakistan \\ *Corresponding author's email: drmzahid@icp.edu.pk \\ Citation \\ Atiq Ur Rahman, Muhammad Zahid and Amjad Ali. Iron deficiency anemia (IDA) in preschool children of district \\ Dir Lower Khyber Pakhtoonkhwa Pakistan. Pure and Applied Biology. Vol. 8, Issue 1, pp1-8. \\ http://dx.doi.org/10.19045/bspab.2018.700157
}

Received: 23/06/2018 Revised: 15/08/2018

Accepted: 27/09/2018

Online First: 04/10/2018

\section{Abstract}

Iron deficiency anemia is a serious public health problem affecting psychological and physical development, behavior and work performance. Infants, preschool children, school age children and women of child bearing age are at greatest risk of developing iron deficiency anemia. A total of 500 preschool were analyzed from various areas of the sample district for the presence of iron deficiency anemia (IDA). The overall incidence of anemia in preschool children was $43.2 \%$. The prevalence of anemia was $43.6 \%$ in females and $42.8 \%$ in males. A high percentage of anemia was observed in children of 1-2 years age (50.4\%) followed by children of 3-4 years age (42.2\%). The incidence of anemia in preschool children was $55.4 \%$ in lower class, $37.8 \%$ in middle class and $32.3 \%$ in upper class. Out of 216 anemic preschool children 110 male and 106 female children possessed anemia. Among male children $22.6 \%$ possess mild anemia, $20.3 \%$ have moderate anemia and $7.8 \%$ were severely anemic while among female children, $20.8 \%$ are mild anemic, $18.9 \%$ were moderately anemic and $9.2 \%$ were severely anemic. A highest prevalence of anemia exists in children of illiterate parents followed by children of Matric, Bachelor and Master level parents. The incidence of anemia is $57.5 \%, 44.6 \%, 37.2 \%$ and $34.1 \%$ in children of illiterate, Matriculate, Bachelor and Master Level parents respectively. Low parental education, low socioeconomic status of the parents and poverty are the major contributing factors for iron deficiency anemia (IDA). The aim of the present survey was to find out the Iron deficiency anemia (IDA) and its association with the children's gender and parental socioeconomic and educational status in preschool children of district Dir lower Khyber Pakhtunkhwa Pakistan.

Keywords: IDA; Parental education; Psychological development; Socioeconomic status

\section{Introduction}

The insufficient hemoglobin concentration in blood is known as anemia. Hemoglobin is an important part of red blood cells (RBCs), which is synthesized in bone marrow and is oxygen carrier [1]. Lower concentration of hemoglobin cause hypoxia (oxygen deficiency). Iron deficiency anemia (IDA) is caused due to the absence of iron needed to control the production of normal red blood cells. IDA is the third and last stage of iron deficiency which begins when the iron reserve of the body is depleted and results in low serum ferritin concentration. Iron is the 
most important element on the earth. The iron store in foetus occurs during 6-9 months of pregnancy. The content of iron is directly proportional to the body mass, thus children with low birth weight have deficiency of iron. So it is important to monitor the iron status during pregnancy [2]. Neural development occurs rapidly during first year of life and iron is necessary at this stage for neurogenesis and cell differentiation in different parts of the brain [3]. The absorption of iron depends on the quantity of iron, the composition of diet, the behavior of mucosa of upper small intestine where two basic factors are responsible for the absorption of iron i.e the body iron stores and the rate of erythropoises [4]. The absorption of iron is dependent on the nature of iron complex and enhancing (facilitating) and inhibitory factors. The enhancing factors include ascorbic acids, sugars(fructose), lysine, cysteine, histidine (amino acids), citric acids and succinic acids and all kinds of meat. The inhibitory factors are phytates, phenolic compounds (flavonoids), phenolic acids, polyphenols, tannins and calcium and phosphate salts.Iron present in meat and meat products form about 5-10\% of the daily iron intake in most of the industrialized countries while the haem iron content is negligible in developing countries. The average absorption of haem iron in meat containing foods is about $25 \%$. Calcium is the only dietary factor which negatively influences the absorption of haemiron [5]. Nonhaem iron is the basic form of dietary iron. Nonhaem iron is in the form of ferric complex and is found in cereals, vegetables, pulses, beans and fruits. It partially reduces to ferrous form during digestion. The ferric form of iron is reduced to ferrous form, which is more soluble and is easily absorbed and thus acts as a best enhancer [6]. The heme form is present in foods of animal origin (hemoglobin, myoglobin etc.) Vegetables possessnonheme iron. The iron rich foods such as beans have low bioavailability due to the presence of phytates fibers while meat has low iron content but high bioavailability. The milk of mothers and cow possesses the same amount of iron, but the milk of mothers has greater bioavailability than the milk of cow. The lower bioavailability of cow's milk is because of the presence of calcium and phosphate salts content [7]. The major dietary risk factors in children of developing countries are deficiency of iron, folic acids, vitamin $A$, vitamin $B_{6}$, vitamin $B_{12}$ and copper. Anemia is also associated with the deficiency of vitamin $A$, riboflavin and protein [8]. Absorption of iron is related to the needs of the body. If the iron reserve is enough in the body, then iron absorption is inhibited and if the iron quantity is low then its absorption is greatly increased. The requirement of iron is related to the age, so its absorption is also linked with the age of the individual. One year old infants have more rate of iron absorption than individuals of other age groups [9]. The reserve iron is the main source of iron for new born and plays a vital role during pregnancy. The exogenous source of iron is breast milk which can fulfill the requirement of iron up to the age of 6 months [10].

About 750 million children suffer from iron deficiency anemia throughout the world [11]. Iron deficiency cause iron deficiency anemia (IDA) which is more common in developing countries of the world. It is estimated that 700,000 children having 1-2 years age possess iron deficiency and 240,000 suffers from ID [12]. Anemia is linked with poverty, improper sanitation and high rate of diseases in children. In developing countries $43 \%$ preschool children possess iron deficiency anemia [13]. The high prevalence of iron deficiency anemia in these populations is because of excessive use of cow's milk, evaporated milk, prolonged stoppage of breast feeding, Helicobacter pylori infection, low socioeconomic conditions, low body 
weight at the time of birth and use of cow's milk before the age of one year [11]. One out of four peoples, especially the pregnant women and preschool children, possess anemia worldwide. The unwanted effects of IDA are the changed psychomotor development and cognitive function, reduced growth rate, reduced school performance, weak immune system, low resistance to various infections, increased body tension and fatigue. In children under the age of 2 years, the effect of IDA on the psychomotor development and cognitive function is irreversible despite of propertherapy [14]. The estimated median productivity loss due IDA is about $4.05 \%$ of gross domestic product (GDP) [15]. A strong relation exists between a child's health and parent's education status [3].

The socioeconomic status is an important determinant of anemia. The children belonging to poor families have more chances of developing anemia as compared to those children who live in rich families. Poverty and poor sanitation are linked to low income and increase the risks of developing anemia in children [16]. The girls with high income possess lower anemia and utilize more iron and vitamins. There is a decreasing trend in anemia prevalence as household income increases and there is a relationship between household income and serum hemoglobin and ferritin levels [17]. The level of parent's education is also an important factor for children anemia. The educated parents have more earning opportunities through well paid jobs and generally adopt healthy dietary behaviors. In Brazil the mean hemoglobin level in children of secondary school level mothers was $11.5 \mathrm{~g} / \mathrm{dl}, 11.2 \mathrm{~g} / \mathrm{dl}$ for mothers with 5-8 years education, $10.8 \mathrm{~g} / \mathrm{dl}$ for motherswith less than 4 years education [16]. In Palestine the incidence ofanemia was higher in children of noneducated mothers [18].
The high incidence of anemia is associated with low level of education even in developed countries [19]. The prevalence of anemia has got more attention in preschool children and women of child- bearing age [20]. The enzymes required for the formation, functioning and destruction of certain neurotransmitters are also affected by iron deficiency and thus decrease mental capabilities [21]. High prevalence of ID in infants is alarming because it produces negative impact on their short term and long term health status. In short term it will reduce their ability to combat acute infections and will negatively affect their mental development and physical growth while in the long term it will cause short stature, poor school performance and lower capacity for physical work [22].

IDA is highest in cost of treatment after tuberculosis throughout the world. Deficient diet during conception, infancy and childhood badly affects the mental development and learning capabilities and imposes a burden on country's expenditures in education, health, productivity and development sectors. The undernourished children are more vulnerable to various diseases and death. Pakistan is a potential victim of diseases due to micronutrient deficiencies which has caused a huge loss of GDP. Approximately 3 billion US dollars are spent annually for the treatment of diseases caused by micronutrient deficiencies. A full fledge andtimely micronutrient intervention can reduce this cost to 83 million USS. More careful approaches are required during pregnancy and early years of life to reduce economic and health loses caused by malnutrition in Pakistan [23].

The present survey was conducted in district Dir lower to investigate the presence of iron deficiency anemia in preschool children. This study will provide a base for the study of iron deficiency anemia in the whole Khyber Pakhtunkhwa. 


\section{Materials and methods Selection of site}

Keeping in view the low socioeconomic conditions and low literacy rate, District Dir lower was selected as a site for data collection. The whole District was divided into five clusters i.e Jandool, Timergara, Lal qillah, Talash and Adenzai for data collection. 100 samples of preschool children (Male/Female) were collected from each cluster. Thus a total of 500 preschool children (1-5 years) were studied for IDA.

\section{Designing of questionnaire}

A questionnaire was designed which included information about the age, gender, social class, parent's profession and educational status. The questionnaires were distributed among parents. Some other research methods like clinical observation and interviews of the children were also conducted.

\section{Sample collection}

The blood samples $(3 \mathrm{ml})$ were collected from the anticubital vein of the children by means of simple syringes and Butterfly tubes in EDTA tubes and were immediately transported to laboratory for analysis.

\section{Laboratory tests}

The hemoglobin $(\mathrm{Hb})$, hematocrit (Hct), MCHC (mean corpuscular hemoglobin concentration), red blood cells (RBCs)count, white blood cells (WBCs) count andplatelet count were find out with the help of hematological analyzer model Sysmex Kx21(Made by: Sysmex Corporation)

\section{Results}

A total of 500 preschool children (1-5 years) belonging to both sexes (Males and Females) were tested clinically for the presence of iron deficiency anemia (IDA) from different areas of district Dir lower Khyber Pakhtunkhwa.

Gender wise anemia in preschool children of different areas was as under: In Jandool $35.8 \%$ males and $60.6 \%$ females possessed anemia. In Timergara, $36.5 \%$ males and $45.9 \%$ females werefound anemic. In Lal
Qillah, $51.1 \%$ males and $43.8 \%$ females were found to be anemic. From Talash 48.9\% males and $37.7 \%$ ) females were found anemic. In Adenzai $48.6 \%$ males and $38.0 \%$ females were found anemic. The overall incidence of anemia in males was $42.8 \%$ and in females was $43.6 \%$. Higher incidence $(60.6 \%)$ was found in females of Jandool and lower incidence $(35.8 \%)$ was found in males of Jandool (Table 1)

According to the parents socio economic status, the following results were obtained. Among 193 children from lower class, 107 $(55.4 \%)$ were anemic and $86(44.5 \%)$ were normal. From middle class, 177 children were observed, out of them 67 (37.8\%) were found anemic and $110(62.1 \%)$ were normal. Similarly 130 children were analyzed from upper class, out of which 42 (32.3\%) were anemic and $88(67.6 \%)$ were found to be normal. Thus highest prevalence was found in lower class $(55.4 \%)$ followed by middle class $(37.8 \%)$ and then by upper class (32.3\%) (Table 2)

The educational status of parents was classified into four categories i.e Illiterate, Matric, Bachelor and Master. Total of 120 children of illiterate parents were studied, out of which $69(57.5 \%)$ were anemic and 51 $(42.5 \%)$ were normal. Among 130 children of matriculated parents, 58 (44.6\%) children possessed IDA and $72(55.3 \%)$ were normal. 129 children of Bachelor level parents were observed, $48(37.2 \%)$ out of them were anemic and $81(62.7 \%)$ were declared as normal. Similarly 121 children of master level parents were tested for IDA, $41(34.1 \%)$ children possessed anemia and $80(66.1 \%)$ were normal. Thus the incidence of anemia was high $(57.5 \%)$ in children of illiterate parents followed by children of matriculates (44.6\%), Bachelors (37.2\%) and Master level parents $(34.1 \%)$ (Table 3).

\section{Discussion}

Iron is the most important element which occurs in bivalent ferrous form $\left(\mathrm{Fe}^{+2}\right)$ and 
trivalent ferric form $\left(\mathrm{Fe}^{+3}\right)$ in the earth. Iron is an important mineral in neural processes like myelination, neurotransmitter production and metabolism [24]. The iron stores infoetus occurs in third trimester of pregnancy. The content of iron is directly proportional to the body mass, thus children with low birth weight have deficiency of iron. So it is important to monitor the iron status during pregnancy [2]. Neural development occur rapidly during first year of life and iron is necessary at this stage for neurogenesis and cell differentiation in different parts of the brain [3]. Iron deficiency anemia (IDA) is a serious public health problem. IDA affects psychological and physical development, behavior and working capacity. IDA affects more than 700 million peoples worldwide. Infants, preschool children, adolescents and females of child bearing age are the most vulnerable groups for developing iron deficiency anemia [25].

Table 1. Gender wise distribution of Anemia (IDA) in preschool children (1-5 years) of district Dir Lower

\begin{tabular}{|c|c|c|c|c|}
\hline Area & Gender & No. of Tested Children & Normal Children N (\%) & Anemic Children N (\%) \\
\hline \multirow{2}{*}{ Jandool } & Male & 67 & $43(64.1)$ & $24(35.8)$ \\
\cline { 2 - 5 } & Female & 33 & $13(39.3)$ & $20(60.6)$ \\
\hline \multirow{2}{*}{ Timergara } & Male & 63 & $40(63.4)$ & $23(36.5)$ \\
\cline { 2 - 5 } & Female & 37 & $20(54.0)$ & $17(45.9)$ \\
\hline \multirow{2}{*}{ Lal qilla } & Male & 43 & $20(47.6)$ & $22(52.3)$ \\
\cline { 2 - 5 } & Female & 57 & $33(56.8)$ & $25(43.1)$ \\
\hline \multirow{2}{*}{ Talash } & Male & 47 & $24(51.0)$ & $23(48.9)$ \\
\cline { 2 - 5 } & Female & 53 & $33(62.2)$ & $20(37.7)$ \\
\hline \multirow{2}{*}{ Adenzai } & Male & 37 & $20(51.2)$ & $24(38.6)$ \\
\cline { 2 - 5 } & Female & 63 & $38(62.2)$ & $\mathbf{1 1 0}(\mathbf{4 2 . 8})$ \\
\hline \multirow{2}{*}{ Total } & Male & $\mathbf{2 5 7}$ & $\mathbf{1 4 7}(\mathbf{5 7 . 1})$ & $\mathbf{1 0 6}(\mathbf{4 3 . 6})$ \\
\cline { 2 - 5 } & Female & $\mathbf{2 4 3}$ & $\mathbf{1 3 7}(\mathbf{5 6 . 3})$ & \\
\hline
\end{tabular}

Table 2. Percentage of anemia (IDA) in preschool children (1-5 years) according to socio economic status of parents

\begin{tabular}{|c|c|c|c|}
\hline Economic status & $\begin{array}{c}\text { No of children tested } \\
\text { Children }\end{array}$ & Normal Children N (\%) & Anemic Children N (\%) \\
\hline Lower class & 198 & $86(44.5)$ & $107(55.4)$ \\
\hline Middle class & 177 & $110(62.1)$ & $67(37.8)$ \\
\hline Upper class & 130 & $88(67.6)$ & $42(32.3)$ \\
\hline Total & $\mathbf{5 0 0}$ & $\mathbf{2 8 4}(\mathbf{5 6 . 8})$ & $\mathbf{2 1 6}(\mathbf{4 3 . 2})$ \\
\hline
\end{tabular}

Table 3. Prevalence of IDA in preschool children in relation to parent's educational status

\begin{tabular}{|c|c|c|c|}
\hline $\begin{array}{c}\text { Parents } \\
\text { education }\end{array}$ & $\begin{array}{c}\text { No. of children } \\
\text { tested }\end{array}$ & $\begin{array}{c}\text { No. and \% of normal } \\
\text { children N (\%) }\end{array}$ & $\begin{array}{c}\text { No. and \% of anemic children N } \\
(\boldsymbol{\%})\end{array}$ \\
\hline Illiterate & 120 & $51(42.5)$ & $69(57.5)$ \\
\hline Matric & 130 & $72(55.3)$ & $58(44.6)$ \\
\hline Bachelor & 129 & $81(62.70)$ & $48(37.2)$ \\
\hline Master & 121 & $80(66.1)$ & $41(34.1)$ \\
\hline Total & $\mathbf{5 0 0}$ & $\mathbf{2 8 4 ( 5 6 . 8 )}$ & $\mathbf{2 1 6 ( 4 3 . 2 )}$ \\
\hline
\end{tabular}


The present survey was based on 500 preschool children (1-5 years)of both sexes (Males and Females). This survey was conducted in various areas of district Dir lower, like Jandool, Timergara, Lal Qillah, Talash and Adenzai. Out of 500 preschool children 216 were found anemic. Thus the incidence of anemia was $43.2 \%$. This is considered as a high percentage. The main reason behind this high incidence is that the children couldn't get the required nutritional diet due to various reasons. The incidence of anemia in various areas of district Dir lower was different in males and females. The prevalence of IDA was high in females (43.6\%) than males (42.8\%). In present survey, the incidence of anemia was high $(50.4 \%)$ in children of 1-2 years of age followed by children of 3-4 years $(42.2 \%)$, then by $2-3$ years $(40.7 \%)$ and finally by children of $4-5$ years age $(40.1 \%)$.The children of lower class parents have high incidence of anemia (55.4\%) followed by middle class $(37.8 \%)$ and then by upper class $(32.3 \%)$. A high prevalence $(55.8 \%)$ of anemia was found in lower class children followed by children of middle class $(32.2 \%)$ and upper class (17\%) [3]. The prevalence of anemia is high $(60 \%)$ in children of labours followed by children of employees $(37.5 \%)$ and then by children of business class parents $(25 \%)$. The incidence of anemia is high $(57.5 \%)$ in children illiterate parents and low $(34.1 \%)$ in children of master level parents. Similarly the percentage was $44.6 \%$ in children of matric level parents and $37.2 \%$ in children of Bachelor level parents. The rate of anemia in low maternal education group was $14.9 \%$ and $7.8 \%$ in high maternal education group in Korea. The children of more educated mothers had increased knowledge about health and nutrition which leads to the consumption of quality diet by children [26]. The mean Hb level of Brazilian children, whose mothers had completed 9 years schooling, was $11.5 \mathrm{~g} / \mathrm{dl}$, for mothers with $5-8$ years schooling it was $11.2 \mathrm{~g} / \mathrm{dl}$ and $10.8 \mathrm{~g} / \mathrm{dl}$ for mothers with less than 4 years of schooling [16]. The low literacy rate is associated with high risk of anemia even in developed countries [19].

The incidence of anemia in various areas of district Dir lower is different in different sexes (males and females). The prevalence of IDA is high in females $(42.9 \%)$ than males $(40.5 \%)$. The prevalence of anemia was high in females $(38.9 \%)$ than boys $(31 \%)$ in district Karak [2]. The prevalence of anemia in present survey is high (47\%) in children of lower class followed by middle class $(39.3 \%)$ and upper class $(38 \%)$. The incidence of anemia in lower class children of district Karak was $55.8 \%$, middle class $32.2 \%$ and upper class was $17 \%$ [2].

\section{Conclusion}

The present survey shows that IDA is the most important nutritional deficiency which badly affects the children. Several factors are responsible for the development of IDA in children. These factors include poverty, malnutrition, illiteracy, parent's profession and lack of proper policies and legislation. Parental education is one of the most important contributors to socioeconomic status and is important in reducing the risk of IDA and in increasing the children's consumption of animal source foods. The presence of iron deficiency in district Dir is inversely affected by the level of parental education and adherence to the iron supplementation.

\section{Authors' contributions}

Conceived and designed the experiments: $\mathrm{M}$ Zahid, Performed the experiments: AU Rahman, Analyzed the data: A Ali, Contributed materials/ analysis/ tools: $\mathrm{M}$ Zahid \& AU Rahman, Wrote the paper: M Zahid \& AU Rahman.

\section{References}

1. Critchly J \& Bates I (2005). Haemoglobin colour scale for anemia diagnosis where there is no laboratory: a 
systematic review. Int J Epidemiol 34: 1425-1434.

2. Ullah I, Zahid M, Ismail M \&Sha M (2013). Prevalence of anemia in pregnant women in district karak Khyber Pakhtunkhwa Pakistan. Int J Bio3: 7181.

3. Beard $\mathbf{J}$ (2008). Why iron deficiency is important in infant development. $J$ Nutr 138(12): 2534-2536.

4. Charlton RW \& Bothwell TH (1983). Iron absorption. Annu Rev Med 34:5568.

5. Hallberg L, Bjorn-Rasmussen E \& Howard L (1979). Dietary haem iron absorption. A discussion of possible mechanisms for the absorptionpromoting effect of meat and for the regulation of iron absorption. Scand $J$ Gastroenterol 14: 769-79.

6. Sharp P \& Srai SK (2007). Molecular mechanisms involved in intestinal iron absorption. World J Gastrointerol 13: 4716-4724.

7. Layrisse M, Martinez-torres C \& Roche M (1968). The effects interaction of various foods on iron absorption. Am J Clin Nutr 11: 1175-1183.

8. Thorandeniya $\mathrm{T}$, Wickremasinghe $\mathrm{R}$, Ramanyake R \& Atukorala S (2006). Low folic acid status and its association with anemia in urban adolescent girls and women of child bearing age in Sri Lanka. Brit J Nutr 95(3): 511-516.

9. Dallman PR (1985). Iron deficiency in the wealing: a nutritional problem on way to resolution. Acta Paediatr Scand 323: 59-67.

10. Beard JL, Dawson $\mathrm{H}$ \& Pinero DJ (1996). Iron metabolism: a comprehensive review. Nutr Rev 54: 295-317.

11. Christifides A, Schauer C \& Zlotkin SH (2005). Iron deficiency anaemia in children:addressing a global public health problem within a Canadian context. Paediatr Child Health 10(10): 597-601.

12. Looker AC, Dallman PR, Carrol MD, Gunter EW \& Jhonson CL (1997).Prevalence of iron Deficiency in the United States. JAMA 277: 973-976.

13. Finch CA (1977). Iron nutrition: Food and nutrition in health and disease. Ann NY Acad Sci 300: 221.

14. Lozoff B, Hagrn J, Mollen E \& Wolf AW (2000). Poorer behavioural and developmental outcome more than 10 years after treatment for iron deficiency in infancy. Pediatrics 105: 1-11.

15. Horton S \& Ross J (2003). The economics of iron deficiency. Food Policy 28: 51-75.

16. Kibangou IB, Bouhallab SH, Gwenaele $\mathrm{BF}$, Allouche S, Blais A, Guerin P, Arhan P \& Bougle DL ( 2005). Milk protein and iron absorption. Pediatric Res 58(4): 731-734.

17. Osorio MM, Lira PL \& Ashworth (2004). Factors associated $\mathrm{Hb}$ concentration in children aged 6-59 months in the state of Pernambuco, Brazil. Br J Nutr 91: 307-315.

18. Kim JY, Shin S, Hank K, Lee KC, Kim JH, Choi YS, Kim DH, Nam GE, Yeo HD \& Lee HG (2014). Relationship between socioeconomic status and anemia prevalence in adolescent girls based on the fourth and fifth Korea national health and nutrition examination surveys. Eur J Clin Nutr 68(2): 253-8.

19. De-pee S, Bloem MW, Sari M \& Kiess L \& Yip R (2002). The high prevalence of Low hemoglobin concentrateon among Indonesian infants aged 3-5 months is related to maternal anemia. $J$ Nutr 132: 2215-2221.

20. Soh P, Ferguson EL, Mckenzi JE, Homs MY \& Gibson RS (2004). Iron deficiency and risk factors for lower iron 
stores in 6-24 months old New Zealanders. Eur J Clin Nutr 58(1): 71-9.

21. Saxton J, Carnll S, Van-jaarsveld C \& Warddle J (2009). Maternal education is associated with feeding style. J Am Diet Assoc 109: 894-898.

22. Dallman PR (1986). Iron deficiencyin weanling: A nutritional problem on the way to resolution. Acta Pediatr Scand 323: 59-67.

23. Sayed NE, Gad A, Nofal L \&Netti G (1999). Assesment of the prevalence and potential determinants of nutritional anemia in Upper Egypt. Food Nutr Bull 20: 417-421.
24. Akhtar S, Ismail T, Autokorala S \& Arlappa N (2013). Micronutrient deficiencies in South Asia-current status and strategies. Trends Food Sci Technol 31: 55-56.

25. Georgieff MK (2007). Nutrition and developing brain: nutrient priorities and measurement. Am J Clin Nutr 85: 614620.

26. De-Maeyer E \& Adiels-Tegman (1985). The prevalence of anaemia in the world. World Rapp Trimest Stat Sanit Mond 38: 302-16. 